\title{
Birds Identified on the Capricorn Group during Expedition of R.A.O.U., 8th to 17th October, 1910.
}

\author{
By A. J. Campbell, C.M.B.O.U., and Capt. S. A. White.
}

White-Bellied SeA-EAGLE (Haliaëtus leucogaster).

Each island visited seemed to be the abode of a pair of SeaEagles. Eyries with young were observed and photographed on Mast-Head and Erskine Islands. In the former the nest was in a large Pisonia tree, which was about 60 feet high. The Eagles, when hovering over an island, particularly in the mornings, made Gooselike cackling notes. They did not seem to prey on the birds of the locaiity, but on sea-snakes and fish.

Two nests were discovered on North-West Island, both in Pisonia trees, at either end of the island. One was situated on the highest tree on the island-one of great girth and few limbs. The nest was a huge collection of boughs and sticks, and contained fully-fledged young, which in colour much resemble the Wedgetailed Eagle, and could easily be mistaken for that bird. The other nest also contained young. The old birds were very quiet, and sat by the nest, and allowed one to approach the base of the tree before taking flight. At dusk every evening these fine birds visited the part of the island on which the camp was situated, and would swoop down amongst the Pisonias, from which the Noddy Terns would fly out in clouds; it was always too dark to make sure if the Eagles were in pursuit of the Terns, but we supposed this was the case, otherwise why should they come there at that time-i.e., when the Terns had congregated from the surrounding sea.

PIED CROW-SHRIke (Strepera graculina).

As in the case of the Sea-Eagles, a pair of this Strepera appeared to occupy one or other of the principal islands. On MastHead a pair occasionally approached the camp, and it was pleasant, at times, to hear their loud, familiar calls, or sometimes a clear, single whistle-like note, especially at early morn (Io minutes to 5 o'clock). On first landing at North-West Island we heard a very full liquid note coming from the dense scrub, which resembled the call of some Honey-eater, but much surprise was expressed next day to find that the call was that of the Pied CrowShrike. A colony, apparently, of these birds had taken up their abode on North-West Island, and had brought up young for many years. During the heat of the day these birds kept to the cool shade of the high Pisonias, but in the early morning and evening they frequented the coast-line. The Strepera family have a strong odour as a rule, but the birds inhabiting the islands had a decided musky odour, resembling that of the Mutton-Bird-a circumstance worth following up, for one reason. Birds, for instance, collected on Kangaroo Island (S.A.) did not possess this peculiar smell. Did the Crow-Shrikes obtain their Petrel perfume by some connection with their (the Mutton-Birds') burrows? 


\section{CATERPILlar-EATER (Edoliisoma temuirostre).}

Several male specimens of this interesting species were observed on North-West and Tryon Islands.

\section{Pied Caterpillar-eater (Lalage leucomelana).}

Mr. L. Harrison identified at short range, with glasses, a single specimen of this Caterpillar-eater on Mast-Head Island.

White-SHOUldered CATERPILlAR-EATER (Lalage tricolor).

LEADEN FLYCATCHER (Mviagra rubecula).

Rufous-BREASTED THICKHEAD (Pachycephala rufiventris).

One or two of these birds, probably on migration only, were observed. A male of the first-mentioned was seen, and females of the others. The Thickheads were particularly merry in song on Mast-Head and Heron Islands, while on North-West Island a female was seen, singing loudly, in a group of Pandanus trees.

WESTERN WHITE-EYE (Zosterops westernensis).

Zosterops were numerous, and appeared to breed upon the islands, judging by a few old nests. As at some of our more southern camps, it was delightful to listen to the subdued chorus of the birds' sweet warbling songs at daybreak. Regularly on MastHead they commenced to warble from Io to 5 minutes before 5 o'clock.

White-eyes were observed in great numbers on North-West and Tryon Islands, where, also, the nesting season had not yet commenced. Several skins were procured-the first by Mr. J. W. Mellor.

From a critical examination of these skins it is at once noticeable that they are not referable to $Z$. corulescens, but are more in agreement with the description of Quoy and Gaimard's $Z$. westernensis.* Should further research prove them different, we venture to suggest the name $Z$. chlorocephalus, or Green-headed White-eye (on account of the "clean-cut" markings of that colour), the following being the general description :-Male.-Distinct ring of silvery-white round the eye, succeeded by a black line under the eye; head, mantle, upper wing coverts, and upper tail coverts bright olive-green; back grey, blending into the greenish mantle; wings and tail dark brown, the primaries and tail feathers edged with bright olive-green; chin, throat, and under tail coverts greenish-yellow; rest of the under surface greyish-blue, darkest on the chest, and approaching greyish-white on the abdomen. Bill dark brown, the basal half of the lower mandible lighter coloured; tarsus dark grey. Dimensions in inches:-Length, $4 \frac{3}{4}$; wing, $2_{\mathbf{1} 6}^{\mathrm{rx}}$; bill, ${ }_{16}^{7}$; tail, 2 ; tarsus, ${ }_{16}^{11}$.

Dollar-Bird (Eurystomus pacificus).

One bird noticed on Mast-Head Island, and a flock of five or six passed over North-West Island, apparently migrating.

\footnotetext{
* A skin in the Melbourne Museum, from Fiji, supposed to be Z. flaviceps (Peale), resembles exactly the Capricorns bird. $Z$. flaviceps $=Z$. westernensis. (See Brit. Mus. Cat. Birds, ix., p. 155.)
} 
The Emu, Vol. $X$.

PLATE XIX.

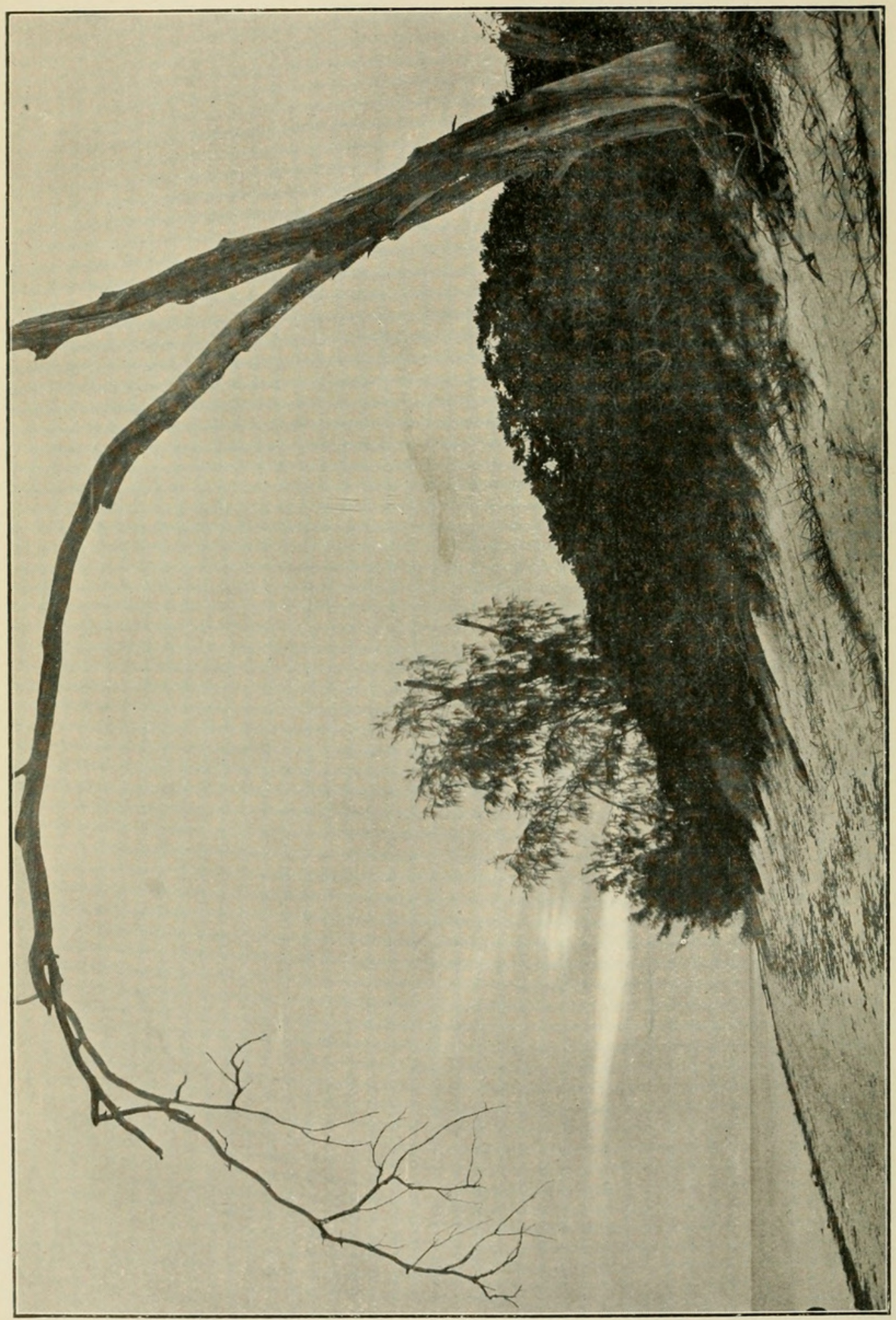

苟

ปै

$3+$

ลิ

ํํำ

ठै

함

पै

요

$\stackrel{0}{\rightarrow} \Xi$

芩

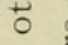

$\div \frac{5}{0}$

동 큰

ฮี

)

है

$\pm 8$

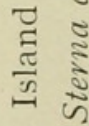

烍 

The Emu. Vol. I

PLATE $X X$.

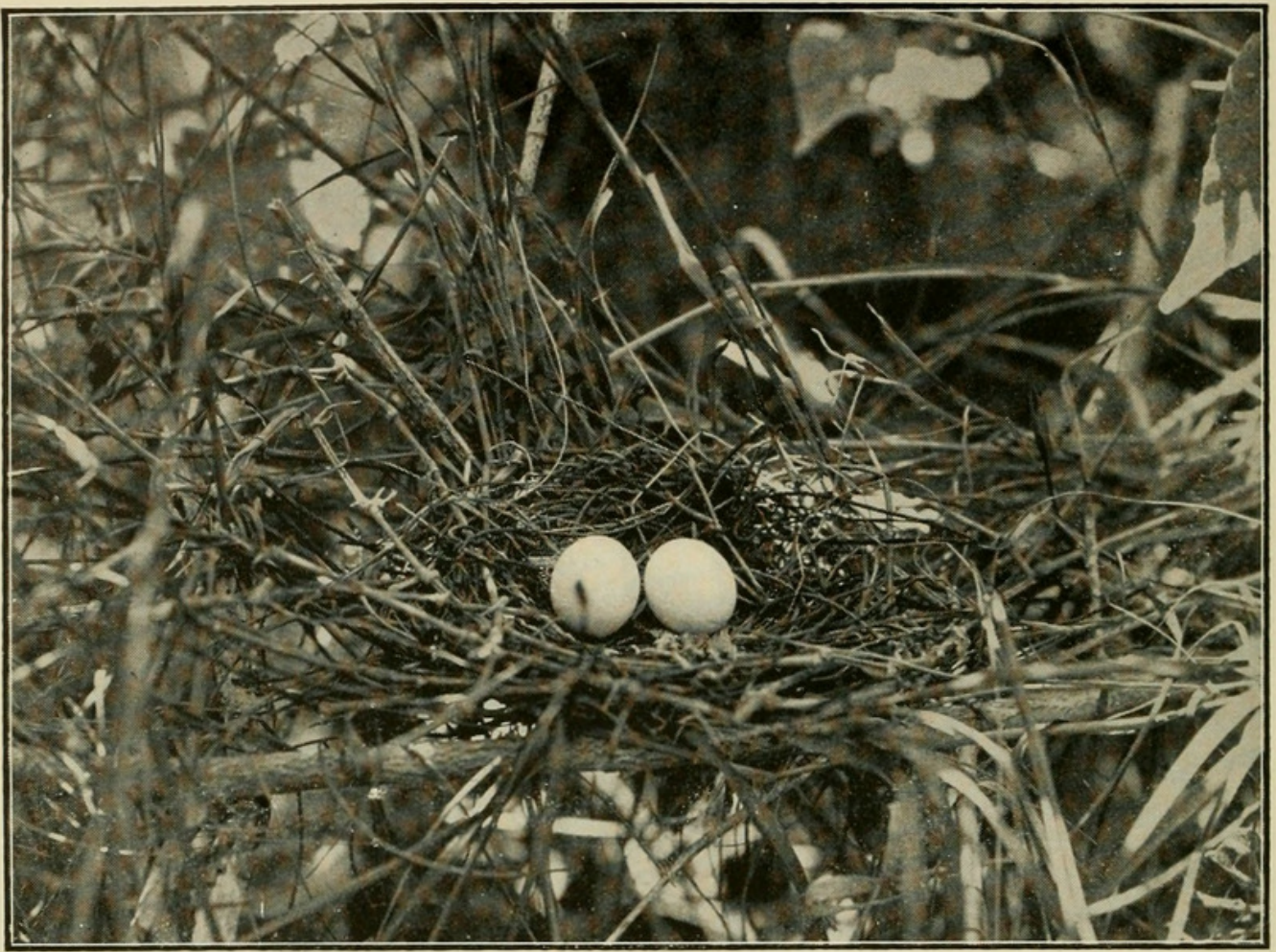

Nest of Barred-shouldered Dove (Geopelia humeralis).

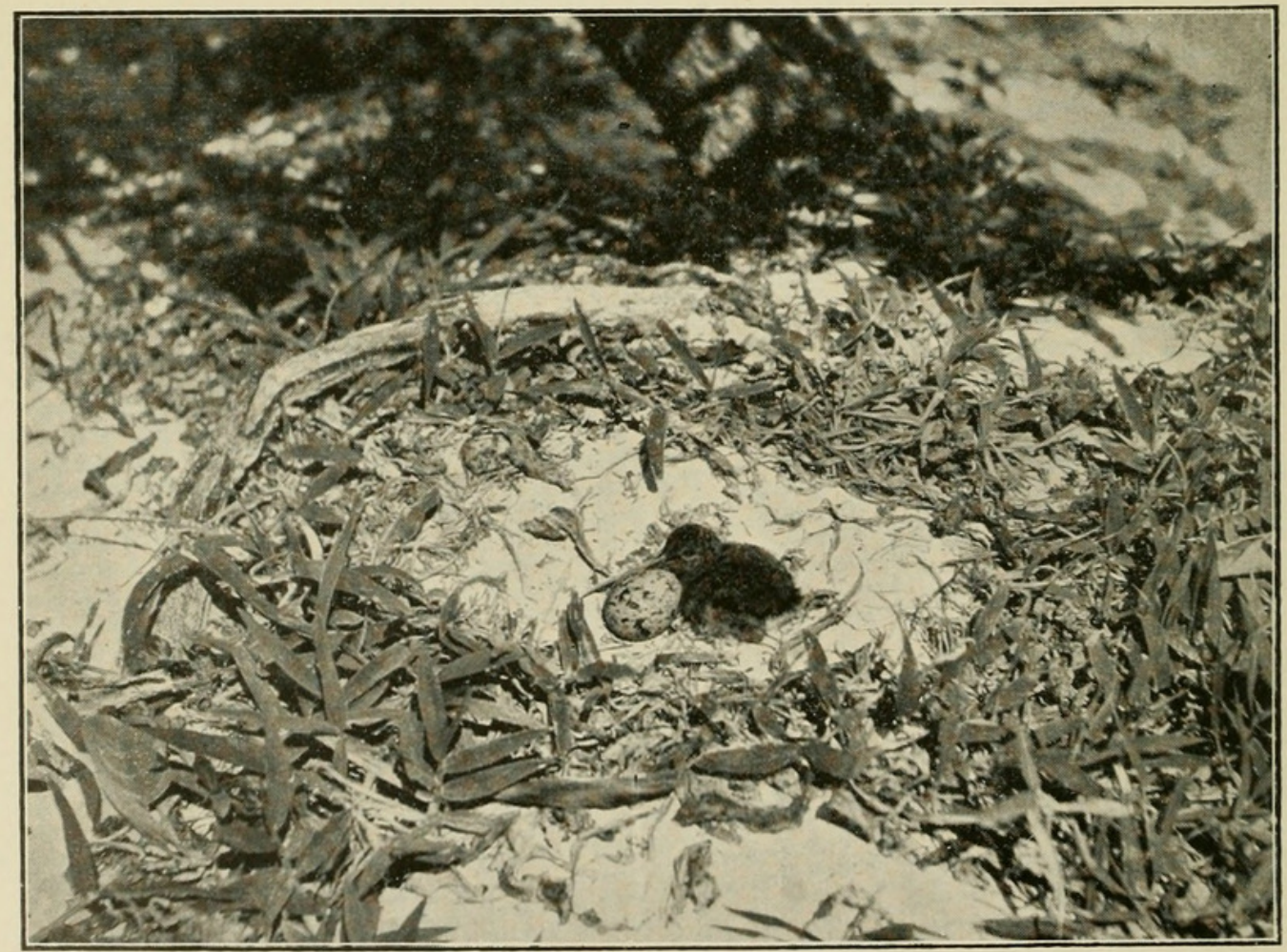

Black Oyster-catcher's (Hamatopus unicolor) Nest. 
SACRED KINGFISHER (Halcyon sanctus).

Some Kingfishers were noticed about the islands similar to the ordinary Sacred species, but more brownish about the breast and flanks. Notwithstanding three struck the steamer's lights one night as she was riding at anchor off the island (proving a migratory disposition), some of these birds remain to breed on the Capricorns, because a nest containing eggs was observed on NorthWest Island. The nesting-place was a hollow limb of a Pisonia tree.

Broad-Billed Bronze-Cuckoo (Chalcococcyx lucidus).

Several beautiful Bronze-Cuckoos, in uniform metallic-green upper plumage, were observed, and specimens secured. These birds were exceedingly tame, catching insect prey near our camps. By dress and song it is not the Bronze-Cuckoo (C. plagosus) of southern parts, but is nearest in description to the New Zealand Shining Cuckoo (C. lucidus). In this opinion Mr. A. W. Milligan and other experts share. The winter home of the New Zealand species is supposed to be Northern Queensland and New Guinea ; if that ba so the Capricorns would be within the fly-line, ${ }^{*}$ while October is about the time these Cuckoos reach New Zealand. The finding of these birds at the Capricorns is one of the interesting features of the expedition of the R.A.O.U.

SouARE-TAILEd Cuckoo (Cacomantis variolosus).

One or two observed, and a skin procured for museum purposes.

KOEL (Eudynamis cyanocephala).

This curious Cuckoo was not observed on North-West Island, but a shining black male was observed on Tryon Island. Probably more were about, but, being alarmed, retired into the denser scrub. What appeared to be a female Koel was noticed on Heron Island.

BARRED-Shouldered Dove (Geopelia humeralis).

Several of these Doves were observed on Mast-Head Island, where a nest and eggs were photographed in a low bush. Very few of these birds were observed on North-West Island. Evidently wild domestic cats have exterminated them several times, but a few odd birds find their way from the other islands. This bird was found on Tryon Island.

Pectoral RaIl (Hypotanidia philippinensis).

Rails with squeaking notes were frequently heard calling, and on two occasions nests with eggs were found. Several dry carcasses or remains of Pectoral Rails were seen in the scrub on MastHead Island. As there were no cats or other enemies likely to kill these birds in this secure retreat, it was a mystery how they came to be destroyed. None was observed on North-West Island, where the cats had destroyed the species; but on Tryon Island Rails were exceedingly plentiful-in fact, so many in such a small p. 93 .

In this connection, see late Capt. Hutton's Presidential Address, Emu, vol. iv., 
area as to excite wonder. A specimen was prepared, and found to be an exceedingly robust form, leading the mainland type in weight by many ounces. The rufous marking was rich and pronounced. The bird was in splendid condition.

Pied Oyster-CATcher (Hamatopus longirostris). SOOTY Oyster-CATCHER (Hamatopus unicolor).

Both these well-known species were noted at intervals round the islands, and were breeding, fully-fledged young and eggs both being observed. The Sooty birds were scarcer and not so confiding as the Pied variety.

TuRnSTONE (Arenaria interpres).

A fair number of these birds was seen on the sandy beaches of Mast-Head, North-West, and Tryon Islands. They appeared to have just arrived, in company with other Waders, from their Northern breeding haunts, and could have had but scant rest or nourishment on the way down, for they were very light and poor.

Lesser Golden Plover (Charadrius dominicus).

A good many of these Plovers were on the beach at Mast-Head and North-West Islands when we arrived, and every day brought fresh arrivals, in an exhausted state. Several of the specimens taken had much of their black Siberian plumage remaining, and in one instance the bird was nearly in its summer dress, its breast being almost black. Plentiful also on Tryon Island.

Common Sandpiper (Tringoides hypoleucus).

Oriental DotTREL (Ochthodromus veredus).

GREY-RUMPED SANDPIPER (Heteractitis brevipes).

These three other migratory species mingled in flocks with Turnstones and Golden Plovers, and were gathered on the reefs at low tide and on the strands at high water. A specimen of the Grey-rumped Sandpiper was taken on shore amongst the grass, evidently exhausted after a long flight. It was in good plumage, but in poor condition. Soon it revived, and was set at liberty. The Dottrel was identified beyond doubt at both camps -Mast-Head and North-West.

A grey-rumped Sandpiper was fairly numerous, which we could only refer to the above-named species, notwithstanding the legs were not so reddish in colour as some authorities describe them.

\section{Little Stint (Limonites ruficollis).}

These small migrants are usually seen in flocks, but two only were noticed at Mast-Head Island. Drs. Macgillivray and Dobbyn observed numbers further north (see page 228).

CURLEW (Numenius cyanopus).

WhIMBREL (Numenius variegatus).

A few Curlews were noticed on the islands. On North-West Island a small flock was seen the day the expedition arrived, but, being timid birds, they departed, and were not observed again. 
The EMU, Vol. $X$.

PLATE XXI,

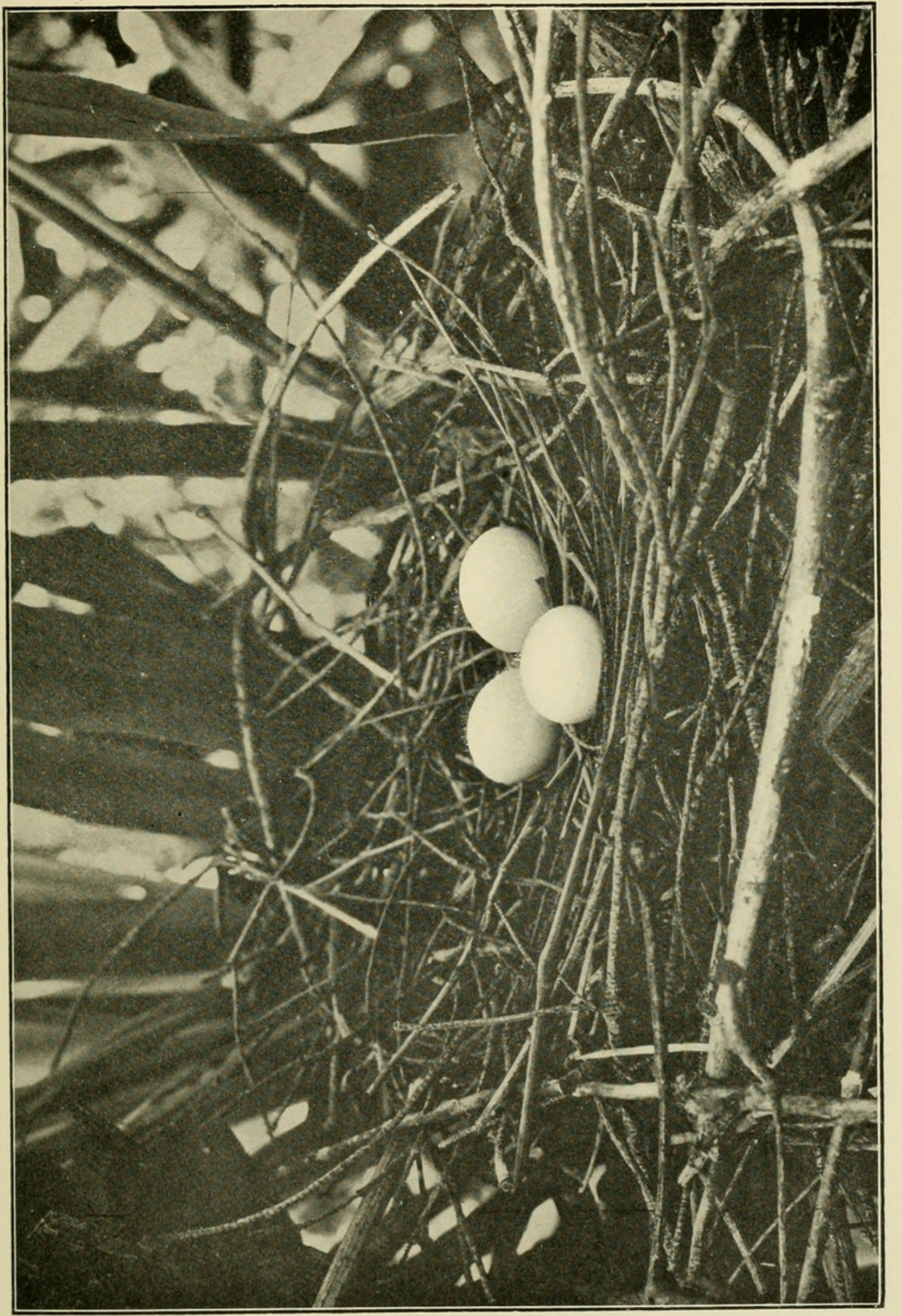

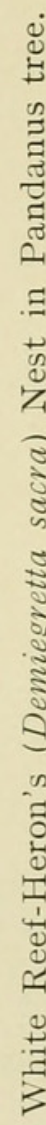





\section{$2 \mathrm{BHL}$ Biodiversity Heritage Library}

Campbell, Archibald James and White, S. A. 1910. "Birds identified on the Capricorn Group during expedition of R.A.O.U., 8th to 17th October, 1910." The Emu : official organ of the Australasian Ornithologists' Union 10(3), 195-204.

View This Item Online: https://www.biodiversitylibrary.org/item/84566

Permalink: https://www.biodiversitylibrary.org/partpdf/244063

\section{Holding Institution}

Smithsonian Libraries

\section{Sponsored by}

Smithsonian

\section{Copyright \& Reuse}

Copyright Status: Public domain. The BHL considers that this work is no longer under copyright protection.

This document was created from content at the Biodiversity Heritage Library, the world's largest open access digital library for biodiversity literature and archives. Visit BHL at https://www.biodiversitylibrary.org. 